\title{
INTRODUCTION TO THE SPECIAL ISSUE ON THE INTERNATIONALISATION OF CENTRAL AND EASTERN EUROPEAN FIRMS
}

\author{
Magdolna SASS* - Péter MIHÁLYI**
}

In the last decades, the internationalisation of firms has attained larger scale and scope, affected more companies and countries and taken a larger variety of forms than previously. This is reflected in the increase in the number of theories, methodologies, papers and research projects dealing with various aspects of firms' internationalisation. Also, policymakers pay greater attention to this topic, all the more so as it is demonstrated by many studies that internationalised companies are usually more competitive, more innovative and perform better than their noninternationalised peers.

In the last three decades, companies in the Central and Eastern European (CEE) region have also been increasingly active internationally and many of them internationalised successfully through various forms, starting from ad hoc exporting to investing abroad. However, their level of internationalisation is still lower than that of the developed country firms - especially those residing in the most developed economies of the European Union. Research conducted so far already indicate certain special 'traits' of the internationalisation of the CEE firms compared to the developed country firms (Dabic - Lamotte 2017), for example their inclination to internationalise in similar countries, and thus, the importance of proximity in various ways in their internationalisation process. On the other hand, compared to the developed country firms, CEE companies face serious lack of resources and capabilities in their internationalisation (Caputo et al. 2016). Another interesting difference is that firms in the CEE countries internationalise quite often because of home country 'deficiencies', e.g. small market or problems with the local business environment. These push factors play an important role in many cases (Jaklič - Svetličič 2003). Pull factors, i.e. motivations include mainly market-seeking (Gorynia et al. 2015), and there does not seem to be a change

\footnotetext{
* Researcher, Center for Regional and Economic Studies, Budapest, Hungary.

E-mail: sass.magdolna@krtk.mta.hu

** Professor at Faculty of Macroeconomics, Corvinus University of Budapest, Hungary, Editorin-Chief of Acta Oeconomica. E-mail: peter@mihalyi.com
} 
towards strategic asset seeking aims over time (Jindra et al. 2015). In many areas, CEE multinationals seem to differ from both their developed and emerging country counterparts (Svetličič 2004), though this difference seem to whither over time (Sass 2018). Furthermore, many CEE firms internationalise in a way, which is connected to their (potential) participation in international value chains.

In the last two-three decades, global or regional value chains have been proliferating in the world economy and involve more and more countries and affect more and more industries. The CEE companies are involved mainly in European, regional value chains, and are very rarely the lead firms. Their participation and the specificities of the industries in question are important determinants of the success of internationalisation of these firms (for a case study see Vlčková 2019). Thus, we can find some interesting specialties in the internationalisation path and process of the CEE firms, which differentiate that group of firms from those operating and internationalising in the developed countries or in the emerging economies. This explains why a closer study of this field may yield in valuable results for the various areas in international business studies, economics or for practical political solutions.

The FDI research group of the Centre for Economic and Regional Studies, formerly affiliated to the Hungarian Academy of Sciences, since its inception in 2013, has organised a series of international and Hungarian workshops on internationalisation of firms. The scarce and rare interactions between the representatives of universities and research institutes, the emergence of new approaches and new theories, and the relative lack of papers dealing with the region explain why the workshops were organised and why they proved to be popular among scholars. The majority of the papers published in this Special Issue were presented on the $8^{\text {th }}$ International Research Workshop of the FDI group, held in November 2018 in Budapest. The authors are indebted to the participants for their valuable comments and suggestions. Furthermore, they are especially grateful for the anonymous reviewers, who, with their advice and comments helped to improve the original manuscripts.

The first two articles concentrate on a selected industry. Csiki et al. analyse the regional-level location decision factors in the European automotive industry. This is among the first attempts in the literature to go down to the regional level in the European Union. The calculations of the paper are based on a comprehensive dataset, which was put together for the purposes of this research. However, lack of regional level trade data could be a problem when interpreting the results as it was pointed out by the reviewers. Thus, according to the results, the most outstanding and dominant location factor is infrastructural development in both the developed and less developed parts of the European Union. Interestingly enough, not only motorways and roads, but also railways and air transport are important. 
That may be related to the fragmentation of production and importance of transportation in making the flow of intermediate and final products easier. Interestingly enough, an efficient labour market and innovation can be important location factors in other than the CEE regions. On the other hand, higher levels of institutions and business sophistication proved to be deterrent factors - this again can be explained by the specialties of the automotive firms, for which a less developed local institutional framework and business sophistication may offer larger opportunities to make their operation more flexible and to exploit their bargaining power - which latter is connected to the fact that they offer a high number of relatively good jobs, compared to other manufacturing industries. Thus, industry specificities matter.

This is the main message of the second article, as well, which concentrates on another manufacturing industry, namely pharmaceuticals (Antalóczy et al.). In Hungary, this industry is of special importance: it has a long tradition and its share is substantial in the economy in terms of production or export. More recently, the Hungarian economy has been integrated into international pharmaceutical value chains. The article shows through calculations based on input-output data that the Hungarian pharmaceutical industry is special: compared to other manufacturing industries it has relatively limited forward and backward linkages. Company interviews reveal, that the two distinct types of production, original and generic, have very different value chains: original (inventing, developing, patenting and producing new drugs) has more linkages, while generic (producing already marketed drugs, for which the patent protection has expired, with using new processes) much less. Furthermore, they differ in terms of their linkages, which are established rather in R\&D than in production. Thus, in spite of the strong specialisation of the Hungarian economy on pharmaceuticals and the presence of important firms, the dominance of generic production explains why the local impact in terms of linkages remains limited.

One of the main players in the Hungarian pharmaceutical industry is one of the leading Hungarian multinational companies: Gedeon Richter. This is one of the companies presented in detail in the Vlčková - Sass paper, which is entitled: 'Just look behind the data! Czech and Hungarian outward foreign direct investment (FDI) and multinationals compared'. First, we show, that compared to balance of payments FDI data, outward FDI by Hungarian-controlled firms may be significantly smaller, and by Czech-controlled firms significantly larger - based on mirror statistics broken down according to the nationality of the ultimate owners of FDI. Second, based on the company case studies, we demonstrate that the leading Czech and Hungarian foreign investor firms can be categorised as "virtual indirect" foreign investors: they are in majority foreign ownership, but under domestic control. In the case of the Czech Republic, some of them are not even 
operating on Czech soil. Furthermore, we underline that the different evolution of outward FDI and local multinationals in the two countries can be related to their different privatisation paths. Thus, we underline the importance of institutions and policies in shaping the outward FDI path.

Manufacturing knowledge and practices usually differ considerably between subsidiaries of multinational companies and local firms. The article by Szász et al. investigates whether the subsidiaries of multinationals in the emerging markets have superior managerial knowledge compared to local companies using data on a large number of manufacturing plants in five emerging economies, including Hungary and Romania from the CEE region. According to their results, indeed: subsidiaries usually have knowledge advantage and invest significantly more in implementing various manufacturing practices compared to local firms, but this superiority is translated into practical dominance over their local counterparts in human resource development and advanced manufacturing technologies only, but not in quality management.

The last two papers deal with a special aspect of the internationalisation using Polish and Hungarian examples. Both are based on detailed company case studies, acknowledging the complexity of the problems and the context-specificity of factors. Mirosław Jarosiński and Krystian Barłożewski compare the strategies of rapidly and incrementally internationalising Polish firms. The literature is abundant in comparing these two types of internationalisers, however, for the CEE countries we can find only a few papers on that topic. The results of the paper are surprising: the authors found more similarities than differences between the two groups of firms in terms of their ownership advantages or motivations. The area where they differed was confined to the higher level of product and process innovativeness and stronger marketing activities of rapid internationalisers. These results may indicate again a special, 'CEE-type' internationalisation path of companies. An interesting sub-group of internationalising firms is that of family firms. Ticián Baranyai and Miklós Kozma concentrated on the Hungarian family firms and based their study on six detailed company cases. They analysed whether generation change affects internationalisation. Their results point to the importance of the supportive style of succession management by the predecessor, which appears to have a strong impact on the internationalisation ambitions and success of family firms under the management of successors. Furthermore, the company cases suggest that internationalisation is a normal step for most family firms in Hungary, indicating that further growth in the internationalisation level of already operating companies can be expected in the future. They also show cases of de-nationalisations or de-internationalisations that can be explained by a defensive strategy aimed at ensuring the survival of the firm in hard times. 
We put together this Special Issue in the hope that the studies presented here contribute to our understanding about the internationalisation of firms, especially in the CEE region. Some of the findings can, however, be of significance for other regions and countries as well. Furthermore, the papers emphasised not only the new results, but also the "deviances" from what we expect based on the theoretical models or experiences of other developed or emerging country firms. Thus, we would like to underscore the CEE-specificities of the result presented in the six papers, which call for further research and for the recognition of the importance of region-specific analyses.

\section{REFERENCES}

Caputo, A. - Pellegrini, M. M. - Dabic, M. - Dana, L. P. (2016): Internationalisation of Firms from Central and Eastern Europe. European Business Review, 28(6): 630-651.

Dabic, M. - Lamotte, O. (2017): Editorial. European Business Review, 29(2): 154 -163.

Gorynia, M. - Nowak, J. - Trapczynski, P. - Wolniak, R. (2015): Outward FDI of Polish Firms: The Role of Motives, Entry Modes and Location Factors. Journal of East European Management Studies, 20(3): 328-359.

Jaklič, A. - Svetličič, M. (2003): The Outward Direct Investment from CEECs: Can Their Firms Compete in the Global Market. Journal for East European Management Studies, 8(1): 67-83.

Jindra, B. - Hassan, S.S. - Günther, J. - Cantner, U. (2015); European Integration and Outward FDI from Central and Eastern Europe - Is There Any Evidence of Knowledge-Seeking? Journal of Common Market Studies. 53(6): 1248-1267.

Sass, M. (2018): Post-Transition Multinationals. Journal of Comparative Economic Studies, 13: 39-64.

Svetličič, M. (2004): Transition Economies' Multinationals - Are They Different from Third World Multinationals? In: Chakraborty, C. (ed.): Proceedings of the 8th International Conference on Global Business and Economic Development, January 7-10, 2004, Guadalajara, Mexico.

Vlčková, J. (2019): SMEs in Medical Technology Global Production Networks: The Case of Czechia. Society and Economy, 41(1): 65-86. 